Volume and Issues Obtainable at Center for Sustainability Research and
Consultancywww.globalcsrc.org

\title{
Role of Local Press in Conflicts: A Case Study of Editorial' Contents ofDaily Chand and Daily Shamal during Militancy in district Swat, Pakistan
}

\author{
${ }^{1}$ Jamal Ud Din, ${ }^{2}$ Rooh ul Amin Khan, ${ }^{3}$ Khalid Khan \\ ${ }^{1}$ Lecturer, University of Swat, Pakistan, jamaluddin@uswat.edu.pk \\ ${ }^{2}$ Asst. Professor, International Islamic University, Islamabad Pakistan, roohul.amin@iiu.edu.pk \\ ${ }^{3}$ Asst, Professor, Department of Media \& Communication Studies, University of Swat, Pakistan, \\ khalid.khan@uswat.edu.pk
}

\begin{tabular}{l}
\hline ARTICLEDETAILS \\
\hline History \\
RevisedFormat: Nov 2015 \\
AvailableOnline: Dec 2015 \\
\hline Keywords \\
Conflict Resolution \\
Role Of Media \\
Militancy And Terrorism \\
Newspapers
\end{tabular}

JEL Classification:

J50, J52, J59,L82

\begin{abstract}
The study "Role of Local Press in Conflict: A Case Study of Editorial' Contents of Daily Chand and Daily Shamal during Militancy in district Swat, Pakistan" is basically a comparison of editorials, being published on the issue of militancy in both the local dailies of Swat to analyze that how these dailies treated government and militants' agendas in their editorials. This study was conducted by content analysis of editorials of Daily Chand and Daily Shamal, publishing from district Swat while the media hegemony theory was applied as theoretical frame work for conducting the study. The findings made it clear that both the dailies had been given more coverage to militants' agenda, the ruling class during the unrest, than government agenda. Daily Chand had written total 84 editorials on the issue of militancy, it wrote 12 (14 percent) editorials against government but not a single editorial had been written against militants. Besides the daily had given only 06 percent supportive coverage to government agenda by publishing 05 editorials while the paper had, however, given more supportive coverage to militants by publishing 17 editorials in favor of their agenda with 20 percent of its total editorials, being published on the issue of militancy. Similarly daily Shamal had written 61 editorials on issue of militancy and of them only three editorials had been written with percentage of 05 percent in support of government agenda while it published two editorials in favor of militants' agenda, which reflect 03 percent of the total editorials, being written on the issue of militancy. Daily Shamal wrote o8 editorials (13 percent) against the provincial government, but it did not write even a single editorial to oppose militants' agenda or their any kind of act, meant to challenge writ of the government in district Swat, Pakistan.
\end{abstract}

(C) 2015 The authors, under a Creative Commons AttributionNonCommercial 4.0

*Corresponding author'semail address:jamaluddin@uswat.edu.pk

Recommended citation:Din, J., Khan, R. A., Khan, K. (2015). Role of Local Press in Conflicts: A Case Study of Editorial' Contents ofDaily Chand and Daily Shamal during Militancy in district Swat, Pakistan. Journal of Business and Social Review in Emerging Economies, 1 (2) 99-108DOI: https://doi.org/10.26710/jbsee.v1i2.12 


\section{Introduction}

The study is designed to examine the role of press in conflicts, where the anti-state elements are trying to gain power and propagate their agenda through media. The certain situation was experienced in district Swat, Pakistan, when the anti-state element i.e. the militants challenged the writ of government during 2007 to2009. The study is aimed at evaluating the editorial coverage about militancy in local newspapers including Daily Chand and Daily Shamal. The local militants were aware of the importance of media, therefore they not only used their own FM radio, known as MullaRadio, but they also propagated their agenda through local print media.

Militants tried to publish those news items, which might create panic so that to gain the support of those believing in their agenda. Militants, who are also called as Taliban, exploited the sentiments of the people of Swat on the name of implementing Islamic Law. Swat, which was merged with Pakistan in 1969, has experienced so many civilizations including Hindu Shahi dynasty, Bhudisim, and Islam, where a large number of temples are now in ruins [1]

\section{Background of Militancy (Talibanization) in Swat}

Due to its strategic importance Swat valley remains in conflict from over the centuries. The phenomena of Talibanization in Swat can be linked to the movement launched in 1994 for the implementation of Sharia (Islamic) Law in all seven distracts of Malakand division, which carried out under the banner of ThereekNifaz-e-ShariatMuhammadi (TNSM). Defunct organization, led by Maulana Sufi Muhammad, was active in Malakand Division, particularly in district Swat.

In 1994 on call of TNS thousands of people come out and demanded Islamic Laws, they blocked the main way to Swat (Malakand Pass) for more than a week, subsequently, the TNSM led protesters challenged the writ of the government for the first after the formation of militant group -TNSM [2]

In July 2007, militants challenged the writ of government in district Swat and took over some sensitive areas of the district including Kabal, Matta subdivisions and its surrounding hilly areas in their control. Which were remained in militiaman's' control till first military operation started in November 2007.

It was a time, when residents of Swat were frightened to speak against the local militants as they had burnt down hundreds of schools and beheaded some of the law enforcement officials.

After military operation government also sought a peaceful solution of militancy in Malakand Division and thus it freed Maulana Sufi Muhammed to initiate dialogue for resolving the issue of militancy.

Sharia Nizam-e-Adl Regulation 2009

On February 16, 2009 the Provincial Government of Khyber Pakhtunkhwa announced, on behalf of Federal Government, to implement Islamic laws in the restive division, Malakand Division. In response Swati Taliban, publicly announced on February 24, 2009 that they would also observe ceasefire for an indefinite time.

In February 2009, the then provincial government reached to an agreement with Maulana Sufi Mohammed, known as Swat Peace Agreement, was criticized by some forces within the country and outside the country as it was agreed to release 300 local militants from jails while, in return local militants would break ties with Tehreek-e-Taliban [3]. Owing to this development and strong recommendations of the National Assembly, former President Zardari signed on April 13, 2009 'Sharia Nizam-e-Adl Regulations 2009'. 
During the process Maulana Sufi withdrawn his support for peace process by claiming that there had been delayed on government part to establish Qazi courts under the signed peace agreement.

At the time local militants also violated the peace agreement by their advancement to district Buner. Sufi also gave a fatwa against courts-present judicial system-, which led the area to such a situation that compelled the government to send army for scuffling militants, because they broke peace agreement [4], and resulted in a full pledge military operation in Swat in May 2009.

\section{Conflict and Media}

Media has been considering an effective medium since their advent, which are molding public opinion about an issue faced by society. In the area of conflict resolution, the media play a major role in informing the people about issue and in making public opinion, and thus, media's role dictates that it should take all steps within its reach to end them as promptly as possible and restore peace. Specifically, in the cases of armed/military conflicts, the objective defined for the media (both print and electronic) is "humanitarian reporting" [5].

A research on topic of 'Conflict Situations and the Media: A Critical Look' conducted by Ajai K. Rai, Research Fellow, IDSA India, mainly highlighted the media role during conflict in Kashmir and Punjab. The researcher argued that though the militants propagate their agendas through guns and bullets but at the same time they used media outlets for their desired goals and the reason that media provides the oxygen of publicity to the militants [6]

This is widely accepted that the materials presented by the media organizations are, mostly, selective. That selectivity is a result of its (media) limited capacity to provide total surveillance. Some factors are imposed on the people while in contrast some financial limitations and economic pressures are also placed on the media because they must survive as profit making commercial organizations. These factors play a vital role to decide which stories to select, follow up, emphasize, interpret and manipulate in a desired way [7].

Media, particularly the press, can motivate the public regarding social, political, religious or cultural issues and give them a particular direction for thinking about the solution of issue faced by the society. Whenever, there is a confrontation between government and a pressure group in a society on an issue, like other institutions media also faced difficulties to discharge their responsibilities according to professional obligations. In such particular situation, media role become more significant, because it has to present an actual position to the general public.

As for as Swat issue is concerned the militancy, mainly, attracted the general public of Swat on the name of Islamic Ideology and Taliban used the media, particularly, the local print media for the motivation of people in this regard.

As local militants (Taliban) were holding the power during Swat crisis (period of militancy, when it was on peak from 2008 to May 2009), so they influenced the society by using various means and ways including use of media for promoting their ideology. As it is believed that idea of the ruling class is become the ruling idea under the concept of 'dominant ideology', the concept- media hegemony- should be applicable on Swat crisis. 


\section{Research Methodology}

The researchers adopted content analysis as research methodology for conducting this research. The Researcher will use the contents analysis method to explore the nature of editorial's coverage of "daily Shamal and daily Chand" about government and militants' agenda. Content analysis had defined by Kerlinger in 1986in these words "a method of studying and analyzing communication in organized, objective and quantitative manner for the purpose of measuring variable is content analysis". Content analysis methods are further divided into quantitative analysis and qualitative analysis.

\section{Objectives of the Study}

1.One of the main objectives of this research is to explore that local press of Swat was tended to project militants' activities in their editorials more than their weight or it given proper space to government as well during the period of Militancy in Swat.

2.To determine the role of local press during the period of militancy.

3.To compare the editorial coverage of government to that of militants.

4.The editorial coverage being given by Local Press to the issue of Militancy in district Swat

\section{Discussion of Results}

The study is mainly conducted to measure the editorial coverage of local newspapers i.e. daily "Chand" and daily "Shamal" in the context of militancy in Malakand Division, particularly in district Swat.

The researchers divided the editorials in five different categories including Pro-Government, ProMilitants, Balance, Anti-Government and Anti-Militants, so for to evaluate the comprehensive treatment of both the dailies and analyze that how they treated the agenda of government and that of militants.

The basic aim of such categorization was to know that how the local newspapers had taken the issue of militancy while they were writing editorials in presence of both government and militants' agendas.

Table $1 \quad$ Editorial coverage of daily Chand

\begin{tabular}{|l|l|l|l|l|l|}
\hline Pro & Pro & Anti & Anti & Balance & Total \\
& Militants & Government & Militants & & Editorials \\
\hline 05 & 17 & 12 & -------- & 39 & 73 \\
\hline $6.84 \%$ & $23.3 \%$ & $16.44 \%$ & $0 \%$ & $53.42 \%$ & 100 \\
\hline
\end{tabular}

Table 1 shows that during the time frame of the research daily Chand had published total 73 editorials on the issue of militancy, which reflected mostly balance coverage of the government and militants' agendas while the paper wrote 12 editorials against government but not a single editorial had been written against militants. 
Daily Chand had given only 06.84 percent supportive coverage to government agenda and its view point about the law and order situation in the restive district Swat by publishing just five editorials in government' support. The paper had, however, given more supportive coverage to militants by publishing 17 editorials in favor of their agenda with 23.3 percent of its editorials, being published on the issue of militancy.

It is shown in the table that the local daily Chand carried out 12 editorials against the provincial government with percentage of 16.44 percent, but it did not publish even a single editorial to oppose militants' agenda or their militant activities in the district as there was comparatively strong hold of militants than that of government.

The daily Chand mainly focused to keep balance in its editorials, being written on the issue of militancy. It had published 39 editorials out of the total 73, which reflected the balance coverage of the issue of militancy. So the paper had given 53.4 percent balance coverage to the issue by urging upon both the provincial government and militants to own the peace agreements and resolve the differences through dialogue instead of use of power.

\subsection{Qualitative Explanation of Daily Chand}

All the five categories are here discussed separately so for to evaluate and analyse the qualitative treatment of editorials, published in daily Chand during the time frame of the study. Figure 1 below depicts the categories of content analysed from editorials of daily Chand.

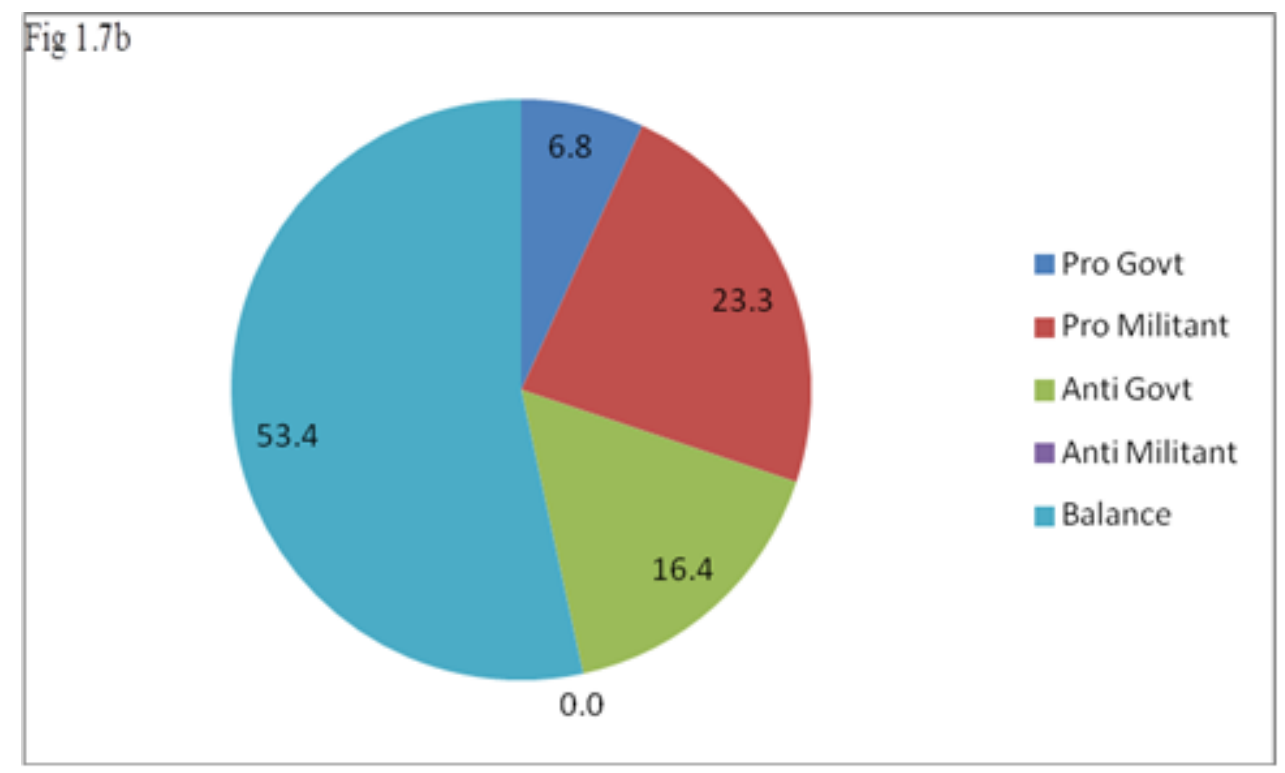

Figure 1: Categorization of the content of editorials of daily Chand

\section{A. Pro-Government}

As the above figure shows that daily Chand had written 6.8 percent editorials in provincial government support, the paper was of the opinion that due to peace agreement the law and order situation in district 
Swat turned to normal. The daily supported the government decision about peace agreement in its editorial published on June 19, 2008 with these words: "people were given mandate to Awami National Party (ANP) for restoration of peace and it has successfully done for peace by signing a peace agreement, which is a great success in part of government"...... (Translation)

Similarly the daily in its editorials published on June 9, 2008, February 17, 2009, April 25,2009 and April 15. 2009 supported the government stance about peace in the region.

\section{B. Pro-Militants}

Daily Chand had published 23.3 percent of its editorials in support of militants (Swati Taliban), which reflected the positive treatment of militants' agenda. It was propagated that militants' basic demand was the implementation of Islamic laws and to achieve such goal they started challenging writ of government in Malakand division, particularly in district Swat.

The paper in its editorial published on September 2, 2009 in background of May' peace agreement, the paper had given opinion in these words: " people of Malakand division have been demanding for Islamic laws since long but unfortunately their demand was not fulfilled even the passage of 61 years.'..... (Translated)

in its editorial published on October 26, 2008, December 20, 2008, January 03, 2009, February 16, 2009, August 04, 2008, January 04,05,13, 19 and 21, 2009, February 25, March 05, 07and 28, April 07 and 11, 2009, were written in support of militants. The paper stressed on government to implement Islamic laws in Malakand division and own those promises it made with Swati Taliban during peace dialogue and act according to the peace agreements so for to pave the way for peaceful solution of the issue.

\section{Anti-Government}

Daily Chand published 16.4 percent editorials against provincial government and it criticized ANP-led government for delaying in implementation of the Islamic laws in Malakand division, which subsequently led toward unwilling situation in the area.

An editorial of the paper published on October 28, 2008 stated that, "in spite of one year has been completed since the operation was started, but still peace could not restore. The people had rejected previous rulers and elected those who promised about restoration of peace during last general elections but today public issues are increasing and the law and order situation has become worst, so expectations relating to the new government did not fulfill.".......... (Translated)

The paper in its editorial published on December 21, 2008, February 02, 2009, September 26, 2008, October 22, 2008, November 09 and 12, 2008, January 01, 17, 24 and 27, 2009 and May 11, 2009 was of the opinion that people' expectations from the newly elected provincial government did not fulfill and resultantly the problems of people increased, which compelled them to leave their homes in first week of May 2009 and spend life as Internally Displaced Persons (IDPs) in other district of the province.

\section{Anti- Militants}


Daily chand did not publish even a single editorial against militants during the period of militancy in district Swat, it reflects that local press preferred to write editorials that suggested and advice both government and militants to adopt the way of negotiations for resolving the issue of militancy.

\section{E. Balance editorials}

Daily Chand published 53.4 percent balance editorials out of 84 editorials, written on the issue of militancy during the time frame of the study. The paper mainly stressed on government as well as militants to avoid the use of power and resolve the issue of militancy or other differences through dialogue.

The paper stated in its editorial published on August 03, 2008 "the peace agreement signed on May 21, 2008 is now in danger; however Government ant Taliban did not announce the ending of the peace agreement so therefore government and militants restore the suspended dialogue and spoil the foreign conspiracy."........ (Translated)

The daily wrote balance editorials on August 23, 2008, September 11, 2008, October 20, 2008 ,January 15, 2009 ,February 15, 2009, February 22, 2009, March 12, 2009, June 7 and 24, 2008, July 01, 05 and 29, 2008, October 15, 2008, November 18 and 20, 2008, December 03, 08 and 14, 2008, January 11, 2009, February 16, 18, 19, 21, 23 and 26, 2009, March 01, 02, 03, 04, 10, 14, 18 and 26, 2009 and April 12, 20, 21, 26 and 29, 2009. In most of the aforementioned editorial daily Chand stressed on both the parties i.e. government and local militants to resolve the issue of militancy through peaceful means.

Table 2 Editorial Coverage of daily Shamal

\begin{tabular}{|c|c|c|c|c|c|}
\hline Pro & Pro & Anti- & Anti- & Balance & Total \\
& Militants & Government & Militants & Editorials \\
\hline 03 & 02 & 08 & -------- & 34 & 47 \\
\hline $6.4 \%$ & $4.3 \%$ & $17 \%$ & $0 \%$ & $73.3 \%$ & 100 \\
\hline
\end{tabular}

Table2 shows that daily Shamal had been written only three editorials with percentage of 6.4 percent in support of government agenda and its view point about the law and order situation in district Swat. Unlike daily Chand the daily Shamal had given less editorial support to the militant agenda as it had published only two editorials in favor of militants' agenda, which reflect just 4.3 percent of the total editorials, being written on the issue of militancy.

The table shows that daily Shamalpublished08 editorials against the provincial government with percentage of 17 percent, but it did not write even a single editorial to oppose militants' agenda or their any kind of act, meant to challenge writ of the government in district Swat.

Like daily Chand the daily Shamal also focused to remain balance in its most of editorials. Daily Shamal had written 34 editorials out of the total 47 , which reflected the balance coverage of the issue and hence the paper had given 73.3 percent balance coverage to both the provincial government and militants' 
agenda by urging them to resolve the differences through dialogue instead of use of power and it stressed on implementation of all the decisions to whom both parties agreed upon in peace agreements.

\subsection{Qualitative Coverage of Daily Shamal}

To evaluate and analyse the editorial coverage of daily Shamal the researcher also conducted his research qualitatively and all the categories are thoroughly evaluated and analyzed to draw conclusion accordingly. Here all the five categories are discussed separately to analyze the qualitative treatment of editorials, published in daily Shamal during the time frame of the study.

\section{A. Pro-Government}

The figure1.7d.shows that daily Shamal published 6.4 percent editorials that supported government agenda regarding the issue of militancy and it appreciated the various steps, being given by government for resolving the law and order situation in Malakand division generally and in district swat particularly.

The paper stated in its editorial published on March 21, 2009 that "there was unrest in district swat from the last two years and demand about implementation of Islamic laws was arisen, the government while taking step upon the willingness of both the sides (Militants and Government) announced Islamic laws' implementation, which resulting in improving the law and order situation."................... (Translated)

Daily Shamal also supported the government' efforts for making practical the peace agreements and urged the government insure implementation so that people could be benefited of its decisions in its editorials published on April 14 and 16, 2009.

\section{B. Pro-Militants}

Unlike daily Chand, the daily Shamal had published 4.3 percent editorials in favor of militants. One editorial was published after the first agreement signed between government and local militants in May 2008 and the other one was published after the second agreement signed in February 2009. Daily Shamal in its editorial published on June 02, 2008 supported the process of speedy justice that was initiated by local militants after the first agreement, the paper stated that "Thereek-e-Taliban Swat have been disposed up 23 different cases in Sakhra, which had been hanging from the last 20 years."............... (Translated)

Daily Shamal supported the demand of local militants by terming it as people' demand and urged government implement Islamic laws in Malakand division, it stated in its editorial published on January 14, 2009 (after the seconded peace agreement) "the residents of Malakand division including district swat are demanding the implementation of Islamic laws and if the government resolve the issue according to the wishes of public then people would be benefited of speedy justice." $\ldots . . . . . . . . . .$. (Translated)

\section{Anti-Government}


Like daily Chand, the daily Shamal also wrote eight editorials against government with percentage of 17 percent. The paper, mainly, criticized provincial government for being delay in implementation of Islamic laws in Malakand division.

Daily Shamal stated in its editorial published on November 24, 2008 that "due to lack of legislation at government level, people in Swat and other tribal areas are compelling to make laws themselves and (it is reported) that so many times punishments had been awarded under Islamic laws in Swat and other parts of the area." .............. (Translated)

The daily in its editorials published on February 01, 2009,April 21, 2009,November 28 and 30, 2008, December 02, 2008, January 28, 2009 and February 07, 2009 criticized government on ground that it was failed to functional government' departments in the restive district Swat.

\section{Anti- Militants}

The daily Shamal also did not publish even a single editorial against militants during the period of militancy in district Swat; it indicates that local press preferred to write editorials that based on suggestions and advice to both government and militants to adopt the way of negotiations for resolving the issue of law and order in district Swat.

\section{E. Balanced Editorials}

Daily Shamal had published34 balance editorials written on the issue of militancy. The daily put stress on government as well as militants to avoid the use of power and resolve the issue of militancy through dialogue while it also suggested both the sides to resolve their differences through peaceful means instead of use of power.

Daily urged both the government and local militants to act according to peace agreement signed between them in May 2008. It expressed its view in editorial published on June 19, 2008 in these words "if government and Taliban will not act according to the peace agreement then civil war would start in whole district and such a situation will bring dire consequences." ..... (Translated). Similarly the daily Shamal in its editorials published on December 25, 2008, February 11, 2009, March 02, 2009, June 03,16, 18, 25 and 26, 2008, November 05, 10, 17 and 23, 2008, December 01, 06, 07, 22, 27 and 30, 2008, January 13, 15 and 17, 2009, February 05, 10, 12, 14, 15,16, 17, 24 and 25, 2009 and April 23, 28 and 29, 2009 stressed on government and militants to take meaningful steps for resolving the issue of militancy in district Swat.

\section{Conclusion}

The study analyzed and evaluated the role of local press in Swat crisis and the results being derived from a thoroughly study of interplay of editorials, Government and Militants' Agenda reflect that local press was comparatively tended towards militants' agenda than that of government agenda. General findings confirmed that local press had given more support to militants' agenda and highlighted their activities both in editorials and news portion of newspapers, because of the hold of militants in the restive district Swat and other parts of Malakand division. So it has been derived from the study that local press was tended to project militants' agenda because of fear and threat. 


\section{References}

Amineh, A (2006) 'Sorrow and Joy Among Muslim Women: The Pukthuns of Northern Pakistan', Cambridge University Press, P- 21

Khan, $\mathrm{R}$ 'Inside rebel Pakistan cleric's domain', Associated Press report. http://www.aboardthedemocracytrain.com/swat-operation-back-to-the-future

Retrieved February 9, 2013

http://en.wikipedia.org/wiki/Tehreek-e-Nafaz-e-Shariat-e-Mohammadi

Retrieved November 05, 2012

http://www.aboardthedemocracytrain.com/swat-operation-back-to-the-future retrieved November 11, 2013

Justice P.B.Sawant (2005), Mass Media in Contemporary Society, Government Central Press, (p. 154)

Justice P.B.Sawant, Mass Media in Contemporary Society, p. 154.

McCombs, M.E and Shaw, D.L. (1972) "The agenda-setting function of mass media". Public Opinion Quarterly,36 (2) 